\title{
Spatial and temporal variability of denitrification in the sediments of the northern Baltic Proper
}

\author{
Liisa Tuominen ${ }^{1, *}$, Anne Heinänen ${ }^{1, * *}$, Jorma Kuparinen $^{1}$, Lars Peter Nielsen ${ }^{2}$ \\ ${ }^{1}$ Finnish Institute of Marine Research, PO Box 33, FIN-00931 Helsinki, Finland \\ ${ }^{2}$ Department of Microbial Ecology, Institute of Biological Sciences, University of Aarhus, Ny Munkegade, Building 540, \\ DK-8000 Aarhus C, Denmark
}

\begin{abstract}
Denitrification in the sediments of the open northern Baltic Sea was measured using the isotope pairing method. The highest denitrification activity was found in the central Gulf of Finland, where denitrification varied between 150 and $650 \mu \mathrm{mol} \mathrm{N} \mathrm{m} \mathrm{m}^{-2} \mathrm{~d}^{-1}$ The bulk of the denitrification was coupled to the $\mathrm{NO}_{3}{ }^{-}$production by nitrification. The mass of benthic fauna was found to be the most significant factor affecting the rate of denitrification. Denitrification rate was highest in late summer and early autumn. Calculated as an average for the Gulf of Finland, the denitrification rate obtained in the present study is $45 \mathrm{kt} \mathrm{N} \mathrm{yr}^{-1}$. This gives a release of ca $30 \%$ of the external $\mathrm{N}$ input by denitrification.
\end{abstract}

KEY WORDS: Denitrification B Baltic Sea Isotope pairing method Sediment

\section{INTRODUCTION}

Denitrification is the bacterial process in which $\mathrm{NO}_{3}$ and $\mathrm{NO}_{2}{ }^{-}$are successively reduced to gaseous $\mathrm{N}_{2}$. The process occurs mainly in the absence of oxygen and is centered at the oxic-anoxic interface where denitrifying bacteria have access to $\mathrm{NO}_{3}^{-}$. These kinds of interfaces appear both in sediment in the littoral and profundal zones and in the water above anoxic deeps. Denitrification removes $\mathrm{N}$ from aquatic ecosystems, and partly counteracts the development of eutrophication, especially in aquatic systems where $\mathrm{N}$ is the limiting nutrient for phytoplankton growth. In the past decades, the nutrient concentrations as well as phytoplankton growth have shown increasing trends in the northern Baltic Sea (Wulff et al. 1990, Perttilä et al. 1995, Rahm et al. 1996) due to a large input of nutrients by human activities. In recent years, it has been shown that $\mathrm{N}$ is the most limiting nutrient in the Baltic Proper and the Gulf of Finland (e.g. Granéli et al. 1990, Kivi et al. 1993), and P in the Bothnian Bay (e.g. Alasaarela et

•E-mail: liisa.tuominen@fimr.fi

- Present address: Academy of Finland, PO Box 99, FIN00501 Helsinki, Finland al. 1986, Granéli et al. 1990). At the same time, however, discussion has been going on about the necessity of reducing $\mathrm{N}$ in waste water (Rinne 1988, Granéli et al. 1990, Seppänen 1992, Tamminen 1992a, b) with one open question being the intensity of the 'natural' purification by denitrification

Denitrification has been calculated to efficiently remove $\mathrm{N}$ from the Baltic Sea ecosystem and therefore counteract eutrophication (Shaffer \& Rönner 1984, Rönner 1985). Shaffer \& Rönner (1984) calcuiated that 80 to $90 \%$ of denitrification takes place in sediments. However, direct measurements of denitrification in the open Baltic Sea have been carried out (and published) mostly with regard to the water column (Rönner \& Sorensson 1985, Brettar \& Rheinheimer 1991, 1992) with only 1 sediment study in the Gulf of Bothnia (Stockenberg \& Johnstone 1997). All these studies used the acetylene blockage method. This method has some pitfalls, especially when applied to sediment samples, including the inhibition of nitrification providing $\mathrm{NO}_{3}{ }^{-}$for denitrification, and the reversal of the blockage of $\mathrm{N}_{2} \mathrm{O}$ reductase by sulfide (Sørensen et al. 1987, Seitzinger et al. 1993, Lohse et al. 1996).

This study presents direct measurements of denitrification in the sediments of the open northern Baltic Sea 


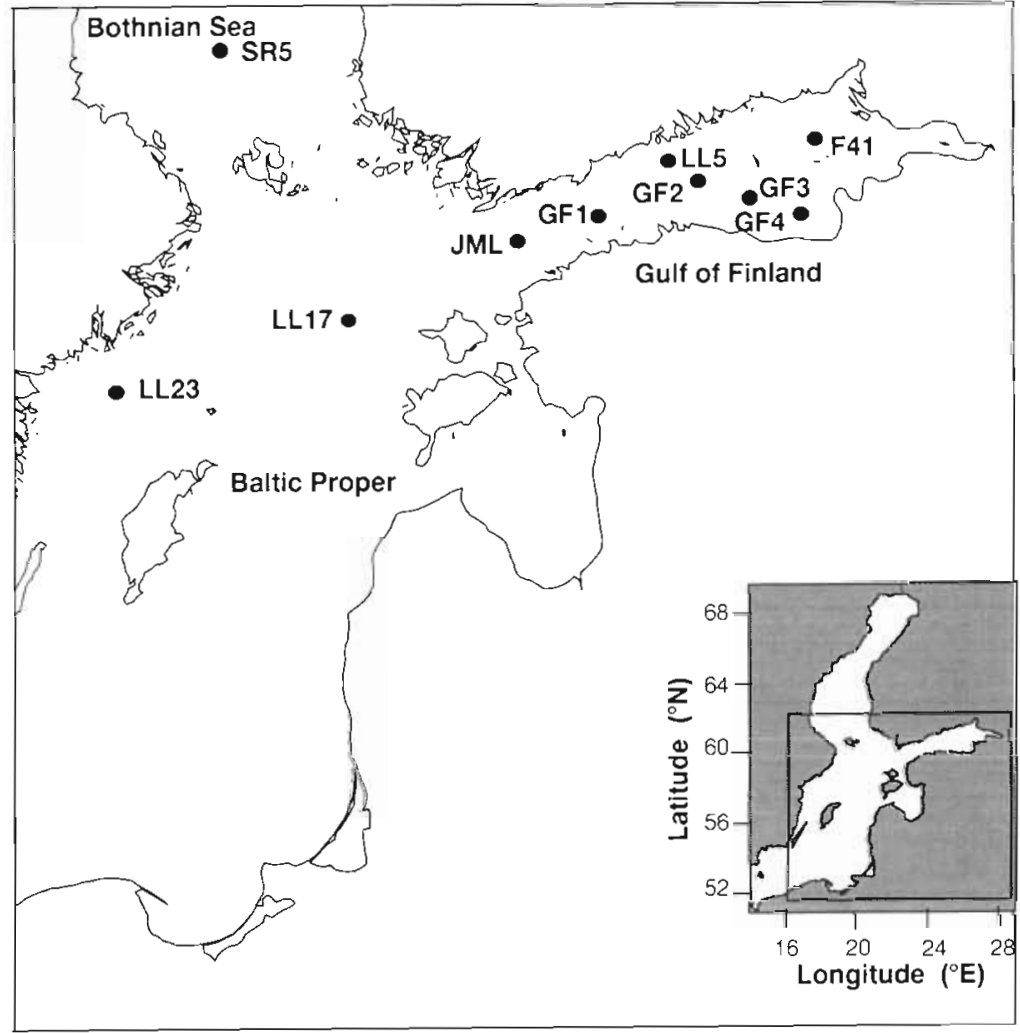

Fig. 1. The sampling stations in the northern Baltic Sea sampled with a Gemini twin-corer (corer tube $\varnothing 8 \mathrm{~cm})$. Water samples for the analyses of $\mathrm{NO}_{3}^{-}$and $\mathrm{NO}_{2}^{-}$(Grasshoff 1983) and $\mathrm{O}_{2}$ concentrations (Winkler titration) were collected from the nearbottom water (ca 1 to $2 \mathrm{~m}$ above the bottom.) on the same days and analysed immediately aboard (except $\mathrm{NO}_{3}{ }^{-}$and $\mathrm{NO}_{2}{ }^{-}$on the $\mathrm{RV}$ 'Alkor' cruise, which were frozen and analysed later). Temperature and salinity were determined with a SeaBird CTD probe.

Sediment denitrification was assayed with the isotope pairing method (Nielsen 1992). In each Gemini twin-corer tube, 3 replicate incubation cores (plastic cylinders with a height of ca $100 \mathrm{~mm}$ and $\varnothing$ $26 \mathrm{~mm}$ ) were pushed into the sediment so that about half of the core length was filled with sediment and the rest with near-bottom water. The top of the incubation core was closed with a cap, the cores were gently lifted from the sediment, and the bottom was closed. In a temperature controlled room set at the near-bottom temperature, $\mathrm{K}^{15} \mathrm{NO}_{3}$ solution (99 atom\%, Europa Scientific Ltd) was added to the water phase of the incu-
The sampling stations represented depositional areas in the Gulf of Finland, in the Bothnian Sea and in the northern Baltic Proper. Denitrification was measured with the isotope pairing method (Nielsen 1992), which is a powerful method to study denitrification without major disturbances to the samples. In this method, sediment samples are incubated. with ${ }^{15} \mathrm{NO}_{3}^{-}$, which, after diffusion to the denitrification zone, pairs with the indigenous ${ }^{14} \mathrm{NO}_{3}{ }^{-}$Total denitrification and denitrification based on the $\mathrm{NO}_{3}{ }^{-}$produced in the sediment by nitrification and on the $\mathrm{NO}_{3}{ }^{-}$diffusing from the water can then be calculated from the amount of ${ }^{29} \mathrm{~N}_{2}$ and ${ }^{30} \mathrm{~N}_{2}$ formed

\section{MATERIAL AND METHODS}

Sediment samples were collected aboard RV 'Viktor Bujnickij' (in January 1996), RV 'Alkor' (in July 1997) and RV 'Aranda' (all other sampling occasions) during cruises in the northern Baltic Proper and southern Bothnian Sea in 1994 to 1997 . The sampling stations represented depositional areas in the northern Baltic Sea (Winterhalter 1972, Kankaanpää et al. 1997) with depths ranging from 30 to $446 \mathrm{~m}$ (Figs. 1 \& 2). Sediment was bation cores near the sediment surface. The concentration used in normal incubations was $100 \mu \mathrm{M}$. The cores were then closed with caps equipped with magnetic stirring bars and incubated in the dark at in situ temperature with the stirring bars rotating slowly. After the incubation, the denitrification was stopped by adding $1 \mathrm{ml}$ of $\mathrm{ZnCl}_{2}\left(1 \mathrm{~g} \mathrm{ml}^{-1}\right)$ to the water phase of the cores, and the cores were gently mixed using a glass stick. This procedure has been found by sequential mixing and resampling to cause only a $3 \%$ loss of ${ }^{15} \mathrm{~N}_{2}$ (unpubl. results). Thereafter, part of the slurry was transferred using a $10 \mathrm{~cm}$ piece of Tygon tubing fitted to a plastic syringe into two $10 \mathrm{ml}$ gas-tight exetainers containing $250 \mu \mathrm{l}$ of the $\mathrm{ZnCl}_{2}$ solution to prevent further microbial activity. In 1994-96 both of the 2 subsamples were

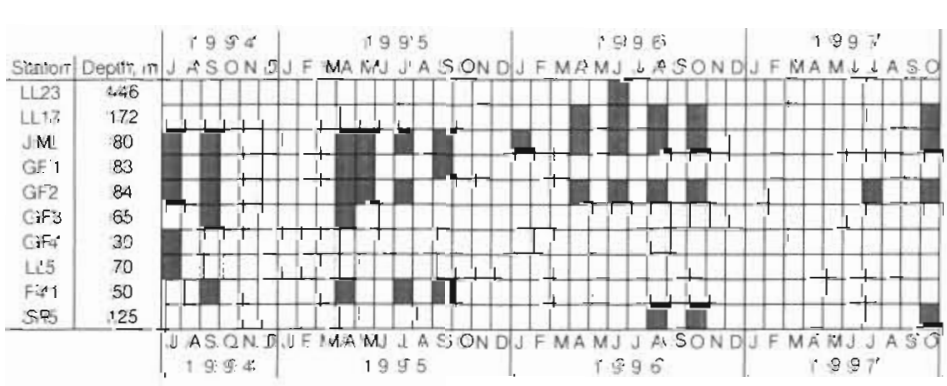

Fig. 2. Frequency of sampling for the stations 
analysed, but in 1997 the second subsample was only analysed if there were problems with the analysis of the first one (since the variability between the subsamples was low, see 'Results'). After replacing $4 \mathrm{ml}$ of the suspension in the exetainer with helium gas followed by vigorous shaking, the mass ratios of $\mathrm{N}_{2}$ in subsamples of the gas phase were analysed using a mass spectrometer at the National Environmental Research Institute in Silkeborg, Denmark.

For the calculation of results, the water content $(w$, by drying at $70^{\circ} \mathrm{C}$ ) and the porosity $(p)$ of the samples were determined. The porosity was calculated as:

$$
p=(w \rho) /[100+w(\rho-1)]
$$

where $\rho=2.6$.

The denitrification rate based on the natural ${ }^{14} \mathrm{NO}_{3}{ }^{-}$ was calculated from the ratios of ${ }^{29} \mathrm{~N}_{2}\left({ }^{14} \mathrm{~N}^{15} \mathrm{~N}\right)$ and ${ }^{30} \mathrm{~N}_{2}$ $\left({ }^{15} \mathrm{~N}^{15} \mathrm{~N}\right)$ formed during the incubation. These were calculated by dividing the 29 and 30 currents given by the mass spectrometer by the current of 28 . Atmospheric air was used as reference and analysed after every 5 or 6 samples. The average of the reference samples before and after the actual samples was subtracted from the results. The results so obtained were transferred into $\mu \mathrm{M}$ by multiplying them by the solubility of $\mathrm{N}_{2}$ to sea water at in situ temperature and salinity (Kester 1975).

The denitrification rate based on the added ${ }^{15} \mathrm{NO}_{3}{ }^{-}$ $\left(D_{15}\right)$ is the sum of all ${ }^{15} \mathrm{~N}$ species formed (Nielsen 1992):

$$
D_{15}=\left({ }^{14} \mathrm{~N}^{15} \mathrm{~N}\right)+2\left({ }^{15} \mathrm{~N}^{15} \mathrm{~N}\right)
$$

When the added ${ }^{15} \mathrm{NO}_{3}{ }^{-}$and the natural ${ }^{14} \mathrm{NO}_{3}{ }^{-}$are uniformly mixed in the sample, the in situ denitrification rate based on natural ${ }^{14} \mathrm{NO}_{3}^{-}\left(D_{14}\right)$ is:

$$
D_{14}=D_{15}\left({ }^{14} \mathrm{~N}^{15} \mathrm{~N}\right) /\left[2\left({ }^{15} \mathrm{~N}^{15} \mathrm{~N}\right)\right]
$$

The denitrification rate obtained was changed into umol $\mathrm{N} \mathrm{m}^{-2} \mathrm{~d}^{-1}$ by multiplying $D_{14}$ by the total water volume of the sample (= volume of water phase + volume of sediment $x$ porosity) and by dividing by the surface area of the sample and the incubation time.

$D_{14}$ can be divided into denitrification based on $\mathrm{NO}_{3}{ }^{-}$ diffusing into the sediment from the overlying water $\left(D_{\mathrm{w}}\right)$ and on $\mathrm{NO}_{3}{ }^{-}$produced in the sediment by nitrification $\left(D_{n}\right)$ (Nielsen et al. 1996). $D_{\mathrm{w}}$ is calculated using the ratio of ${ }^{14} \mathrm{NO}_{3}{ }^{-}$and ${ }^{15} \mathrm{NO}_{3}{ }^{-}$available in the water phase:

$$
D_{\mathrm{w}}=D_{15} a / b
$$

where $a=$ natural concentration of $\mathrm{NO}_{3}{ }^{-}$in the nearbottom water, and $b=$ added concentration of ${ }^{15} \mathrm{NO}_{3}{ }^{-}$

$D_{\mathrm{n}}$ is thereby:

$$
D_{\mathrm{n}}=D_{14}-D_{\mathrm{w}}
$$

The optimal incubation time was determined by incubating samples for 1, 3 and $5 \mathrm{~h}$. The time series incubations were performed at Stns F41, GF1 and JML. The first-order kinetics and the minimization of the formation of unmeasurable ${ }^{14} \mathrm{~N}^{14} \mathrm{~N}$ pairs were ensured by incubating the samples with increasing concentrations of ${ }^{15} \mathrm{NO}_{3}^{-}(10$ to $100 \mu \mathrm{M})$ and by plotting the $D_{15}$ and $D_{\mathrm{n}}$ results obtained with the concentration used (Nielsen 1992). These experiments were performed at Stns LL17, JML and GF2.

The sources of variation in the denitrification measurements were identified by comparing coefficients of variation between ${ }^{15} \mathrm{~N}$ measurements from a single incubation core ( 2 subsamples), between the 3 incubation cores collected from a single Gemini core and between the Gemini cores.

\section{RESULTS}

\section{Methodological tests}

The time series incubations showed that the denitrification was linear for at least $5 \mathrm{~h}$ at Stns F41 and JML, whereas at GF1 large variation in results was found after $5 \mathrm{~h}$ incubation (Fig. 3). Sediment oxygen consumption measured during the same cruises as the denitrification was between 7 and $30 \%$ (on 4 occasions 30 to $40 \%$ ) during $3 \mathrm{~h}$ incubation (Haahti \& Karjala unpubl. results). This gives the upper limit for incubation time in the denitrification measurements since a major decline in the $\mathrm{O}_{2}$ concentration during the incubation may affect the denitrification rates directly or through changes in the nitrification rates. Consequently, $3 \mathrm{~h}$ incubations were used in all of the later samplings.

The kinetic experiments revealed that the saturation of $D_{14}$ was achieved using ${ }^{15} \mathrm{NO}_{3}{ }^{-}$addition of ca $100 \mu \mathrm{M}$ (Fig. 4a, c). Thus, at that concentration, the production of the unmeasurable ${ }^{14} \mathrm{~N}^{14} \mathrm{~N}$ was minimized. The addition of $100 \mu \mathrm{M}^{15} \mathrm{NO}_{3}{ }^{-}$(which is a very high concentration compared to the natural concentration) did not affect the first-order kinetics of denitrification, which can be seen from the linear increase in $D_{15}$ as the ${ }^{15} \mathrm{NO}_{3}{ }^{-}$concentration increased (Fig. 4b, d). Consequently, for these types of sediments, $100 \mu \mathrm{M}$ of ${ }^{15} \mathrm{NO}_{3}{ }^{-}$was the ideal concentration. Stn LL17 had very little $\mathrm{O}_{2}$ (see Fig. 5) which theoretically explains why $D_{15}$ became nonlinear above $50 \mu \mathrm{M}$ and why $D_{\mathrm{n}}$ consequently ciecreased (Fig. 4e, f)

The subsamples taken from a single incubation core for the ${ }^{15} \mathrm{~N}$ analysis showed little variation (coefficient of variation $9.9 \%$ ). Consequently, in 1997 only 1 subsample was measured. The coefficient of variation between incubation cores pushed into 1 single Gemini core was $26.2 \%$, and between cores collected from a 

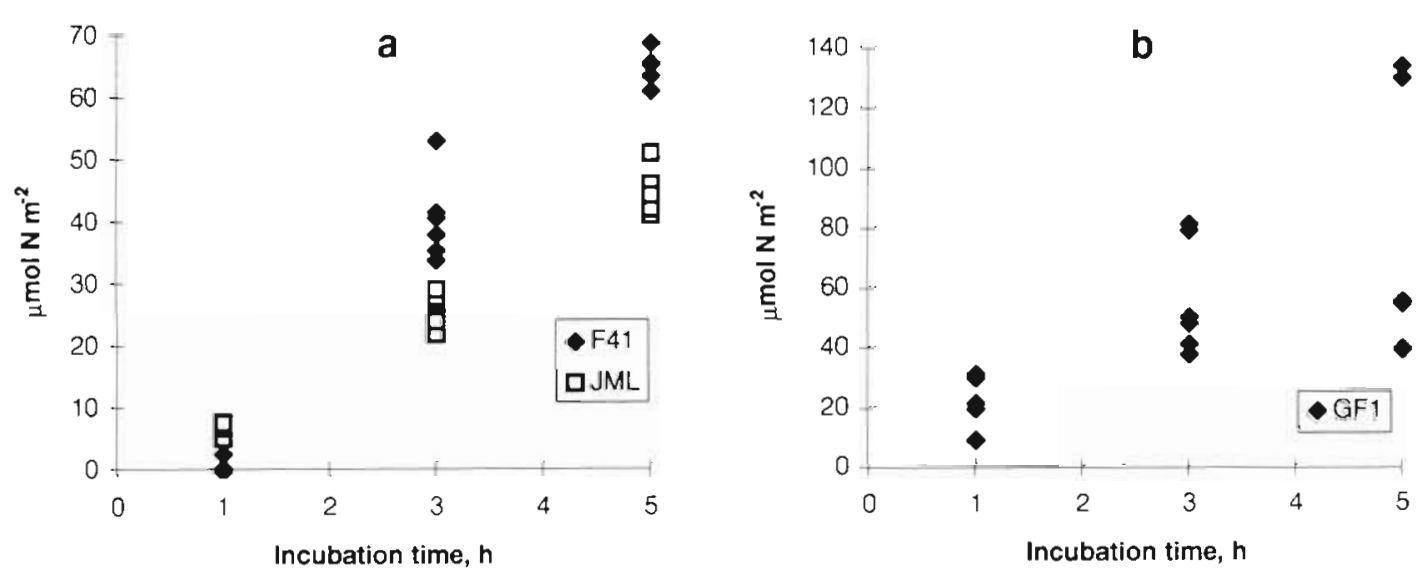

Fig. 3. Results from the time series incubations for samples collected from Stns (a) F41, JML and (b) GF1

single station $34.1 \%$. Thus, a large part of the total variation was detected within 1 corer tube suggesting that the variability on the sea floor occurred on a $\mathrm{cm}$ scale.

\section{Hydrographical data}

The salinity in the near-bottom water was 5.5 to 6.5 in the Bothnian Sea and in the eastern Gulf of Finland. Westwards of this in the Gulf of Finland, the salinity increased to ca 7.5-8.5 at Stn GF2 and to 8.5-9.5 at JML at the entrance to the Gulf of Finland. In the northern Baltic Proper (Stns LL17 and LL23), the salinity was 10 to 10.5 . The temperature varied between 0.8 and $4.9^{\circ} \mathrm{C}$, with the lowest temperatures at the shallowest stations.

The $\mathrm{O}_{2}$ and $\mathrm{NO}_{3}{ }^{-}$concentrations near the bottom are shown in Fig. 5. The $\mathrm{O}_{2}$ concentration was lowest at Stns LL23 and LL17 in the northern Baltic Proper (Fig. 5e, f), and highest at SR5 in the Bothian Sea (Fig. 5f) and at F41 in the eastern end of the Gulf of Finland (Fig. 5d). The $\mathrm{NO}_{3}^{-}$concentration in the nearbottom water was lowest at Stn SR5 in the Bothnian Sea (ca $5 \mu M_{i}$ Fig. 5f). In the Baltic Proper (Stns LL17 and LL23), the concentration was slightly above $10 \mu \mathrm{M}$, while in the Gulf of Finland it fluctuated around $10 \mu \mathrm{M}$ (Fig. 5). The $\mathrm{NO}_{2}^{-}$concentration was always very low $(0$ to $0.2 \mu \mathrm{M}$, except for $0.7 \mu \mathrm{M}$ at LL17 in August 1996 and $1.0 \mu \mathrm{M}$ at F41 in July 1995).

\section{Denitrification}

The highest denitrification activity was found in the central Gulf of Finland, at Strus GF1, LL5, GF2 and GF3, where denitrification varied between 150 and $650 \mu \mathrm{mol} \mathrm{N} \mathrm{m} \mathrm{N}^{-2} \mathrm{~d}^{-1}$ (Fig. 6b, c, f). JML, the station at the entrance to the Gulf of Finland and with a water depth of about $80 \mathrm{~m}$, showed lower denitrification activity (100 to $400 \mu \mathrm{mol} \mathrm{N} \mathrm{m} \mathrm{N}^{-2} \mathrm{~d}^{-1}$ ) than the other stations in the Gulf of Finland (Fig. 6a). Denitrification rate was statistically significantly higher (2-tailed t-test, $p=$ 0.039 ) at GF2 than at JML (the 2 stations with most intense sampling). At the eastern end of the Gulf of Finland, at Stn F41, denitrification was 100 to $300 \mu \mathrm{mol}$ $\mathrm{N} \mathrm{m}^{-2} \mathrm{~d}^{-1}$ (Fig. 6d). At the deep stations in the northern Baltic Proper, denitrification rate was $15 \pm 9$ umol N $\mathrm{m}^{-2} \mathrm{~d}^{-1}( \pm \mathrm{SD})$ at LL23 $(446 \mathrm{~m})$ and 125 to $300 \mu \mathrm{mol} \mathrm{N}$ $\mathrm{m}^{-2} \mathrm{~d}^{-1}$ at LL17 (172 $\mathrm{mi}$ Fig. 6e). The result from Stn LL23 is not shown in Fig. 6 due to a different order of magnitude. In addition, the denitrification at Stn LL23 was measured from the top centimeter of the sediment since, due to the loose structure of the sediment, subsampling with the incubation cores was not possible at this station.

At Stn SR5 in the Bothnian Sea, denitrification was between 250 and $300 \mu \mathrm{mol} \mathrm{N} \mathrm{m} \mathrm{N}^{-2} \mathrm{~d}^{-1}$ (Fig 6f). However, at that station negative values were sometimes observed and very high standard deviation was found between replicates (see legend for Fig. 6f). On 1 occasion (August 1996), variation was enormous, with an average of $-2200 \mu \mathrm{mol} \mathrm{N} \mathrm{m}^{-2} \mathrm{~d}^{-1}$ and SD $6400 \mu \mathrm{mol} \mathrm{N}$ $\mathrm{m}^{-2} \mathrm{~d}^{-1}$

Denitrication was usually at its highest in late summer and early autumn, from July to September (Fig. 6a, b) The lowest activity was found in spring during April and May. The only measurement carried out during winter, at Stn JML in January 1996, showed very high denitrification activity $\left(400 \mu \mathrm{mol} \mathrm{N} \mathrm{m}^{-2} \mathrm{~d}^{-1}\right)$, actually the highest measured at JML (Fig. 6a).

At al.1 the other stations except LL17, the bulk of the denitrification was based on $\mathrm{NO}_{3}{ }^{-}$produced in the sediment by nitrification, i.e. coupled nitrification-denitrification $\left(D_{\mathrm{ni}}\right.$ Fig. 6). At LL17, $D_{\mathrm{n}}$ was less than half of the total denitrification (Fig. 6e). The highest $D_{\mathrm{n}}$ per- 

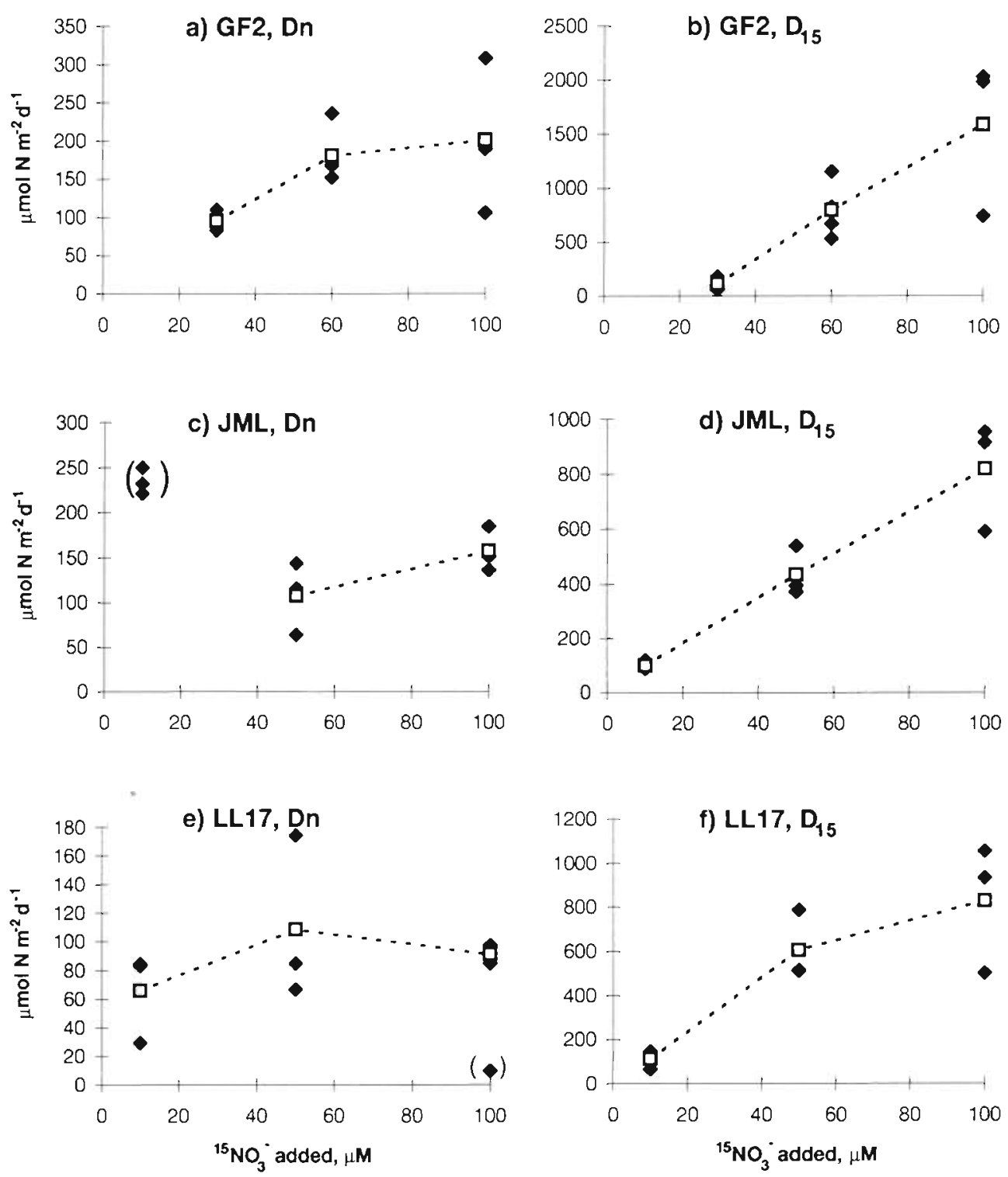

Fig. 4. Saturation kinetic incubations for Stns GF2, JML and LL17. Coupled nitrification-denitrification $\left(D_{n}\right.$ i left panel) and denitrification based on added ${ }^{15} \mathrm{NO}_{3}{ }^{-}\left(D_{15}\right.$; right panel) as a function of the concentration of added ${ }^{15} \mathrm{NO}_{3}^{-}(\bullet)$ Replicates; $(--\square--)$ averages of replicates

centages were found at Stn SR5 in the Bothnian Sea (97 to $100 \%$; Fig. $6 \mathrm{f}$ ) and at F41 at the eastern end of the Gulf of Finland ( 86 to $94 \%$; Fig. 6d). No clear differences were found in the $D_{\mathrm{n}}$ percentages between seasons.

Total denitrification correlated positively with wet mass of benthic fauna and negatively with depth (Table 1). The positive correlation with bacterial production was almost significant at the $p \leq 0.05$ level as well. $D_{w}$ correlated positively with $\mathrm{NO}_{3}{ }^{-}$concentration, salinity and temperature in the overlying water, and negatively with $\mathrm{O}_{2}$ concentration (Table 1). These 4 variables correlated significantly with each other, too (data not shown). $D_{n}$ correlated negatively with depth and salinity, and positively with $\mathrm{O}_{2}$ concentration (Table 1). Benthic fauna had a positive correlation both with $D_{w}$ and with $D_{n}$ as well.

\section{DISCUSSION}

\section{Methodological questions}

One precondition in the isotope pairing technique is a uniform mixing of added ${ }^{15} \mathrm{NO}_{3}{ }^{-}$and natural ${ }^{14} \mathrm{NO}_{3}{ }^{-}$ in the denitrification sites (Nielsen 1992). If uniform 

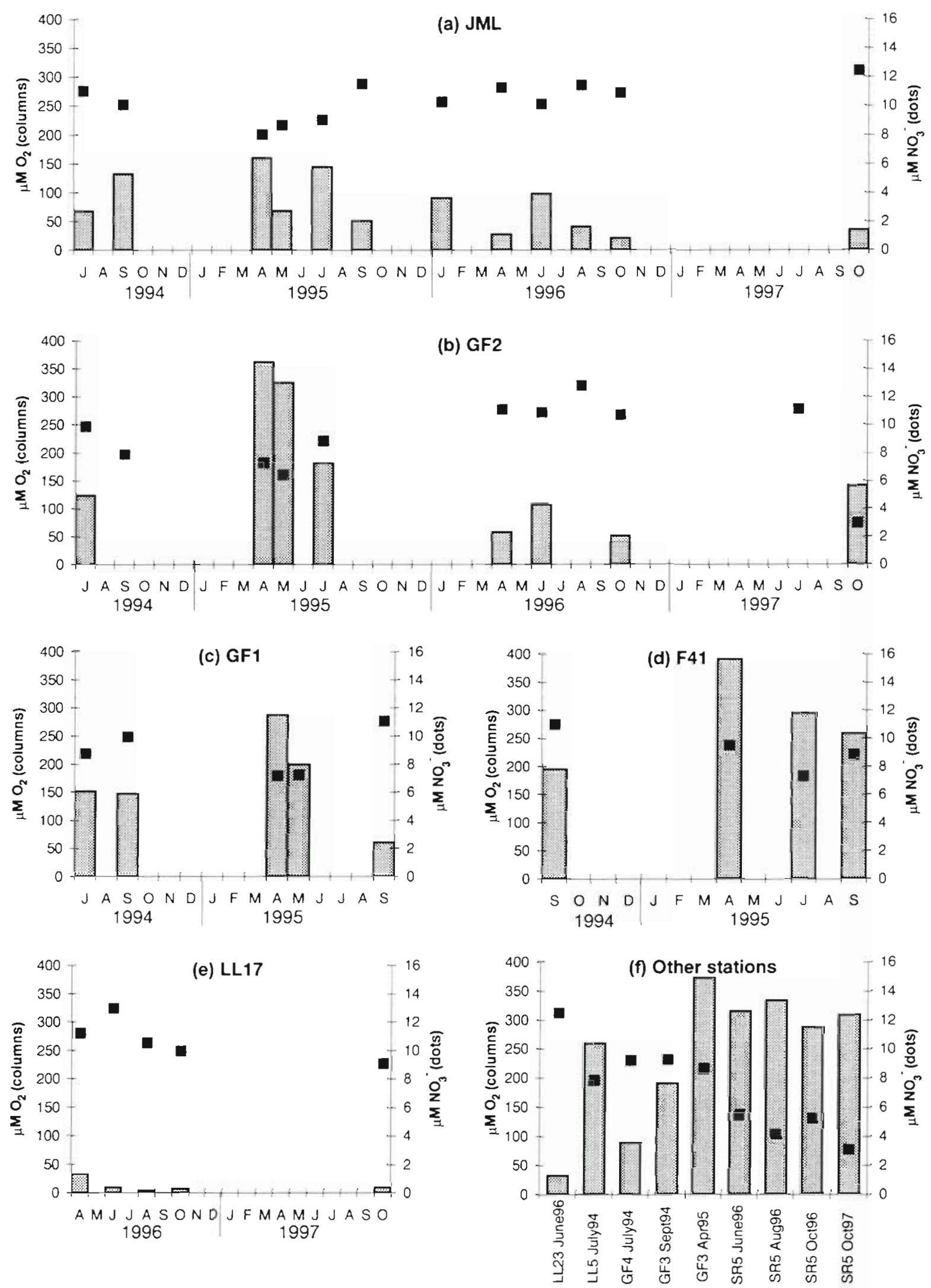

Fig. 5. $\mathrm{O}_{2}$ concentration (columns, left axis) and $\mathrm{NO}_{3}{ }^{-}$concentration ( $\mathbf{a}$, right axis) at stations (a) JML, (b) GF2, (c) GF1, (d) F41, (e) LL17 and (f) other stations. No column: $\mathrm{O}_{2}$ concentration not analysed 

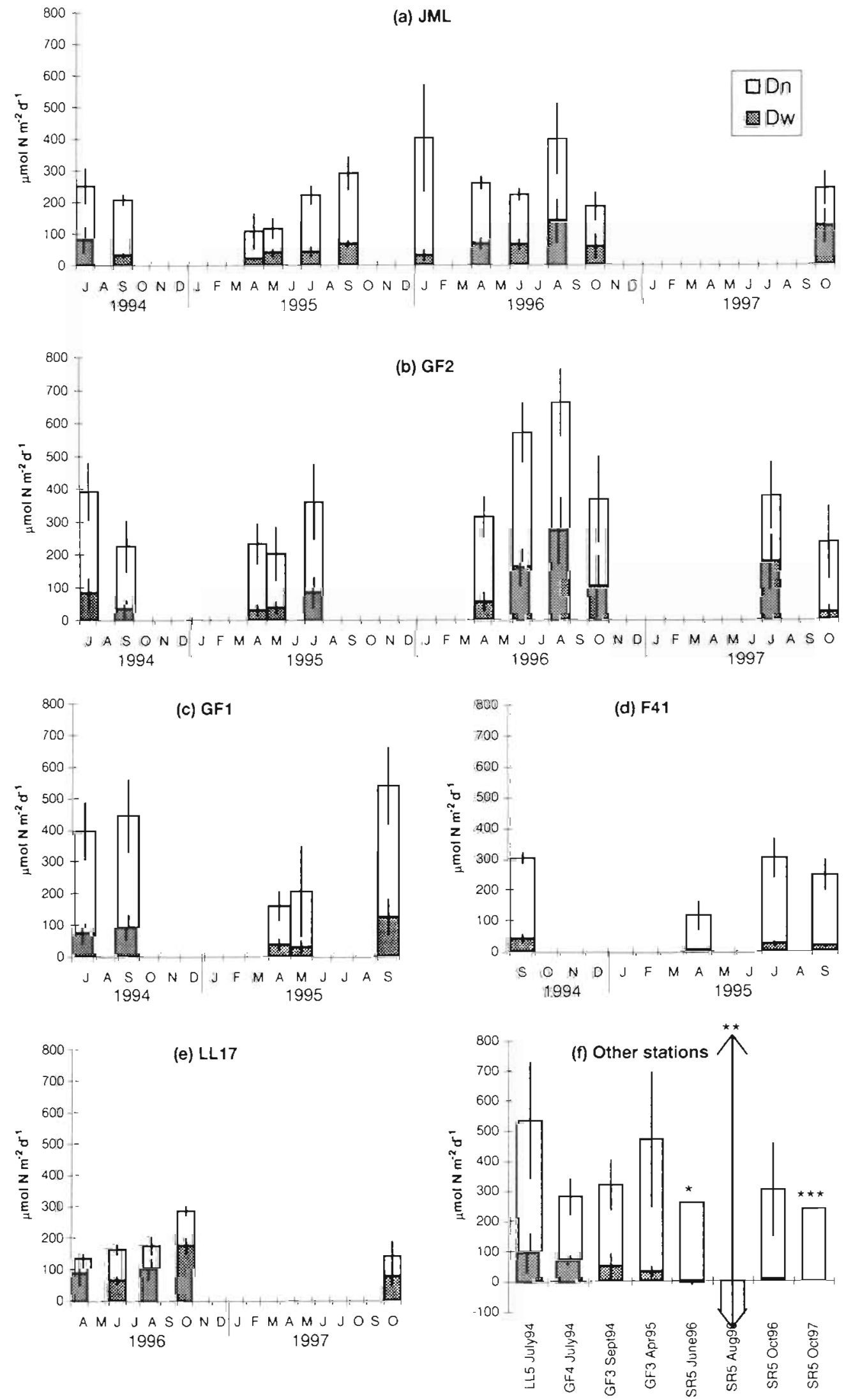

Fig. 6. Denitrification based on coupled nitrification-denitrification $\left(D_{n}\right)$ and denitrification based on overlying water $\mathrm{NO}_{3}{ }^{-}\left(D_{\mathrm{w}}\right)$ at Stns (a) JML, (b) GF2, (c) GF1, (d) F41, (e) LL17 and (f) other stations. Error bars denote \pm SD. Total denitrification $=D_{n}+D_{w}$ ( $*$ ) SD

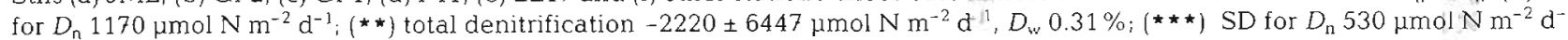


Table 1. Correlation between total denitrification, denitrification based on overlying water $\mathrm{NO}_{-}^{-}\left(D_{\mathrm{w}}\right)$ and coupled nitrification-denitrification $\left(D_{n}\right)$ with various environmental parameters. Number of observations in parentheses. Significant at $p \leq 0.05$ level

\begin{tabular}{|c|c|c|c|}
\hline & Denitrification & $D_{\mathrm{w}}$ & $D_{\mathrm{n}}$ \\
\hline Denitrification & 1 & & \\
\hline$D_{w}$ & $\begin{array}{l}0.52^{\circ} \\
(48)\end{array}$ & 1 & \\
\hline$D_{\mathrm{n}}$ & $\begin{array}{l}0.92^{\circ} \\
(48)\end{array}$ & $\begin{array}{l}0.1 .5 \\
(48)\end{array}$ & 1 \\
\hline Depth & $\begin{array}{c}-0.34^{\circ} \\
(48)\end{array}$ & $\begin{array}{c}-0.05 \\
(48)\end{array}$ & $\begin{array}{c}-0.37^{\circ} \\
(48)\end{array}$ \\
\hline $\mathrm{NO}_{3}^{-}$ & $\begin{array}{c}0.01 \\
(48)\end{array}$ & $\begin{array}{l}0.55^{\circ} \\
(48)\end{array}$ & $\begin{array}{c}-0.24 \\
(48)\end{array}$ \\
\hline $\mathrm{NO}_{2}^{-}$ & $\begin{array}{c}-0.10 \\
(48)\end{array}$ & $\begin{array}{l}0.02 \\
(48)\end{array}$ & $\begin{array}{c}-0.12 \\
(48)\end{array}$ \\
\hline Salinity & $\begin{array}{c}-0.27 \\
(38)\end{array}$ & $\begin{array}{l}0.41^{\circ} \\
(38)\end{array}$ & $\begin{array}{c}-0.51^{\circ} \\
(38)\end{array}$ \\
\hline Temperature & $\begin{array}{c}-0.01 \\
\{38\}\end{array}$ & $\begin{array}{l}0.35^{\circ} \\
(38)\end{array}$ & $\begin{array}{c}-0.17 \\
(38)\end{array}$ \\
\hline $\mathrm{O}_{2}$ & $\begin{array}{l}0.15 \\
(45)\end{array}$ & $\begin{array}{c}-0.58^{\circ} \\
(45)\end{array}$ & $\begin{array}{l}0.36^{\circ} \\
(45)\end{array}$ \\
\hline $\mathrm{O}_{2}$ consumption ${ }^{\mathrm{a}}$ & $\begin{array}{c}-0.18 \\
(30)\end{array}$ & $\begin{array}{c}-0.35 \\
(30)\end{array}$ & $\begin{array}{c}-0.05 \\
(30)\end{array}$ \\
\hline Bacterial production ${ }^{a}$ & $\begin{array}{l}0.45 \\
(1.4)\end{array}$ & $\begin{array}{l}0.27 \\
(14)\end{array}$ & $\begin{array}{l}0.33 \\
(14)\end{array}$ \\
\hline Benthic fauna ${ }^{a}$ & $\begin{array}{l}0.54^{\circ} \\
(21)\end{array}$ & $\begin{array}{l}0.46^{\circ} \\
(21)\end{array}$ & $\begin{array}{l}0.51^{\circ} \\
(2.1)^{\circ}\end{array}$ \\
\hline $\begin{array}{l}\text { Pontoporeial } \\
\text { Monoporeia }\end{array}$ & $\begin{array}{l}0.30 \\
(21)\end{array}$ & $\begin{array}{l}0.22 \\
(21)\end{array}$ & $\begin{array}{l}0.32 \\
(21)\end{array}$ \\
\hline Meiofauna & $\begin{array}{c}-0.08 \\
(13)\end{array}$ & $\begin{array}{c}-0.05 \\
(13)\end{array}$ & $\begin{array}{c}-0.08 \\
(13)\end{array}$ \\
\hline \multicolumn{4}{|c|}{$\begin{array}{l}\text { "Data on } \mathrm{O}_{2} \text { consumption by the sediment, bacterial pro- } \\
\text { duction in the sediment (as leucine uptake), benthic } \\
\text { fauna (wet mass), Pontoporeia/Monoporeia (abundance) } \\
\text { and meiofauna (abundance) kindly provided by the sci- } \\
\text { entists at the Finnish Institute of Marine Research }\end{array}$} \\
\hline
\end{tabular}

mixing is not achieved, denitrification rate will be underestimated, since unmeasurable ${ }^{14} \mathrm{~N}^{14} \mathrm{~N}$ pairs will be formed. This leads to an underestimation in the calculations. Correct results can be achieved by using a sufficiently high concentration of ${ }^{15} \mathrm{NO}_{3}^{-}$after testing the saturation of $D_{14}$. However, it has to be ensured that the high concentration added will not affect the assumed first-order kinetics of denitrification. This is achieved by analysing the potential denitrification $\left(D_{15}\right)$ as a function of the added concentration. In the present study, an optimal concentration was found to be $100 \mu \mathrm{M}$, which is in accordance with results obtained by Pelegrí et al. (1994) and Jensen et al. (1996). Middelburg et al. (1996) concluded after model simulation that the $D_{14}$ estimate is reliable even at high ${ }^{25} \mathrm{NO}_{3}{ }^{-}$concentrations in the water and with a substantial overlap of nitrification and denitrification zones.

SR5, the station in the Bothnian Sea, sometimes showed negative denitrification rates and an enormous variation between replicates (see legend for Fig. 6). At that station, the ${ }^{15} \mathrm{~N}^{15} \mathrm{~N}$ production was at the detection limit with the present incubation time and set up. Therefore, minor variations in the ${ }^{15} \mathrm{~N}^{15} \mathrm{~N}$ ratio had tremendous effects on the calculated $D_{\mathrm{n}}$. The incubation time of $3 \mathrm{~h}$ might have been too short at this well oxygenated station for the ${ }^{15} \mathrm{NO}_{3}^{-}$to diffuse in and for enough ${ }^{15} \mathrm{~N}_{2}$ to accumulate.

\section{Spatial and temporal variability of denitrification}

The rates of denitrification measured from the northern Baltic Proper, the Gulf of Finland and the Bothian Sea were comparable with the rates measured for other estuarine and marine environments (Koike \& Sorensen 1988, Seitzinger 1988, and Table 2). However, the rates measured from the northern Baltic Proper (Stns LL17 and LL23) were lower than e.g. rates measured from the eastern North Pacific continental shelf at comparable depths (Table 2). Evidently, the deep areas of the Baltic Sea have lower denitrification rates than areas in the oceans with the same depths, presumably due to anoxic conditions. Koop et al. (1990) estimated denitrification rates from sediment-water nutrient fluxes and $\mathrm{O}: \mathrm{N}$ flux ratios in the northern Baltic Proper for 3 stations with depths of 47,82 and $130 \mathrm{~m}$. According to the results, no denitrification was calculated to occur at the deepest station, whereas at the $82 \mathrm{~m}$ station the relative $\mathrm{N}$ loss was largest. The mean rate of denitrification at the 2 shallowest stations (1.2 mmol $\mathrm{N} \mathrm{m}^{-2} \mathrm{~d}^{-1}$; Koop et al. 1990) is higher than the results obtained in the present study for stations at the same depths.

The mean denitrification rate in the Gulf of Finland, ca $300 \mu \mathrm{mol} \mathrm{N} \mathrm{m} \mathrm{N}^{-2} \mathrm{~d}^{-1}=4.2 \mathrm{mg} \mathrm{N} \mathrm{m}^{-2} \mathrm{~d}^{-1}$, is about $1 / 6$ of the denitrification rate as calculated for the sediment of the Baltic Proper ( $25 \mathrm{mg} \mathrm{N} \mathrm{m} \mathrm{N}^{-2}$ ) by Shaffer \& Rönner (1984). The rates measured at Stns LL17 and LL23 in the Baltic Proper (present study) are even much lower. Rönner (1985) found in his calculations for the Baltic Proper an unexplained $\mathrm{N}$ loss of $247 \mathrm{kt} \mathrm{N} \mathrm{yr}^{-1}$, which he assumed to be denitrification in the sediments of the Gulf of Finland and the shallow Baltic Proper. The mean denitrification rate found in the present study for the Gulf of Finland multiplied by the area of the Gulf of Finland $\left(29.6 \times 10^{3} \mathrm{~km}^{2}\right)$ gives denitrification of $45 \mathrm{kt} \mathrm{N} \mathrm{yr}^{-1}$ Similarly, this is about $1 / 6$ of the unexplained loss of Rönner (1985).

The highest denitrification activity found in the central Gulf of Finland is most obviously attributable to 
Table 2. Recent estimates of denitrification and coupled nitrification-denitrification $\left(D_{n}\right)$ in estuarine and marine environments

\begin{tabular}{|c|c|c|c|c|}
\hline Location & $\begin{array}{l}\text { Denitrification } \\
\mathrm{mol} \mathrm{N} \mathrm{m}^{-2} \mathrm{~d}^{-1}\end{array}$ & $\begin{array}{l}n \\
-1\end{array}$ & Method & Source \\
\hline Gulf of Finland, Baltic Sea & $100-650$ & $54-95 \%$ & Isotope pairing method & This study \\
\hline Northern Baltic Proper & $15-300$ & $39-67 \%$ & Isotope pairing method & This study \\
\hline Northern Baltic Proper & 1200 & & $\begin{array}{l}\text { Non-stoichiometric loss } \\
\text { of nitrogen }+\mathrm{NO}_{3}^{-} \text {flux } \\
\text { to sediment }\end{array}$ & Koop et al. $(1990)$ \\
\hline Gulf of Bothnia. Baltic Sed & $0-940$ & & $\begin{array}{l}\text { Acetylene blockage } \\
\text { method }\end{array}$ & $\begin{array}{l}\text { Stockenberg \& Johnstone } \\
\text { (1997) }\end{array}$ \\
\hline Norsminde Fjord, Denmark & $3900-5300$ & $16-31 \%$ & Isotope pairing method & Rysgaard et al. (1993) \\
\hline Norsminde Fjord, Denmark & $2100-5200$ & $8-27 \%$ & Isotope pairing method & Risgaard-Petersen et al. (1994) \\
\hline North Sea & $200-300$ & $95 \%$ & Isotope pairing method & Lohse et al. (1996) \\
\hline Wadden Sea, Germany & $0-400$ & $25-31 \%$ & Isotope pairing method & Jensen et al. (1996) \\
\hline River Colne estuary, England & $80-11000$ & $0-81 \%$ & Isotope pairing method & Ogilvie et al (1997) \\
\hline $\begin{array}{l}\text { River Great Ouse estuary, } \\
\text { England }\end{array}$ & $520-2300$ & & $\mathrm{C}_{2} \mathrm{H}_{2}$ blockage & Trimmer et al. (1998) \\
\hline $\begin{array}{l}\text { Nueces and Guadalupe } \\
\text { Estuaries, Texas }\end{array}$ & $200-3400$ & $\begin{array}{l}\text { 'Tight coupling be- } \\
\text { tween nitrification } \\
\text { and denitrification' }\end{array}$ & $\begin{array}{l}\mathrm{N}_{2} \text { prod. in gas-tight } \\
\text { chambers }\end{array}$ & Yoon \& Benner (1992) \\
\hline Gulf of Maine & $700-1000$ & & $\begin{array}{l}\text { Non-stoichiometric } \\
\text { loss of nitrogen }\end{array}$ & Christensen et al. (1996) \\
\hline Boston Harbor & 2600 & & $\begin{array}{l}N_{2} \text { prod. in gas-tight } \\
\text { chambers }\end{array}$ & Nowicki et al. (1997) \\
\hline Massachusetts Bay & 1100 & $\begin{array}{l}\text { 'Most of the N loss } \\
\text { was apparently from } \\
\text { coupled nitrification- } \\
\text { denitrification' }\end{array}$ & $\begin{array}{l}\mathrm{N}_{2} \text { prod. in gas-tight } \\
\text { chambers }\end{array}$ & Nowicki et al. (1997) \\
\hline Chesapeake Bay & $0-2000$ & $\begin{array}{l}\text { 'Denitrification gen- } \\
\text { erally controlled } \\
\text { by nitrification' }\end{array}$ & $\begin{array}{l}\mathrm{C}_{2} \mathrm{H}_{2} \text { blockage } \\
\mathrm{NO}_{3}-\text { balance }\end{array}$ & Kemp et al. (1990) \\
\hline North Atlantic continental shelf & 700 & & $\begin{array}{l}\text { Model (denitrif }=0.019 \times \\
\text { phytoplankton prod.) }\end{array}$ & Seitzinger \& Giblin (1996) \\
\hline $\begin{array}{l}\text { Eastern North Pacific } \\
\text { continental shelf }\end{array}$ & 3200 & $\begin{array}{l}\text { 'Most of the } \mathrm{N}_{2} \\
\text { production is coupled } \\
\text { to nitrification' }\end{array}$ & $\begin{array}{l}\text { In situ benthic } \\
\text { flux chamber }\end{array}$ & Devol (1991) \\
\hline $\begin{array}{l}\text { Eastern North Pacific } \\
\text { continental shelf }\end{array}$ & $800-4800$ & $\begin{array}{l}\text { 'A significant within- } \\
\text { sediment source' }\end{array}$ & $\begin{array}{l}\text { In situ benthic } \\
\text { flux chamber }\end{array}$ & Devol \& Christensen (1993) \\
\hline Western Arctic shelf & $1000-2000$ & & $\begin{array}{l}\text { In situ benthic } \\
\text { flux chamber }\end{array}$ & Devol et al. (1997) \\
\hline
\end{tabular}

higher mass of benthic fauna in that region (data not shown). This is supported by the significant correlation found between benthic fauna and denitrification (Table 1), and was also found previously (Henriksen \& Kemp 1988, Kristensen 1988, Seitzinger 1988, Pelegrí et al. 1994). Since the abundance of benthic fauna fluctuates strongly in the Baltic Sea, depending on the hydrographical regime (Laine et al. 1997), the rate of denitrification may have large temporal variations as well. The years 1994 to 1996 during the present study represented a time-span of very high abundance of benthic fauna, after which the abundance collapsed to about 1/10 (Laine pers. comm.).
Since the bulk of the denitrification was coupled to the $\mathrm{NO}_{3}^{-}$production by nitrification, other factors which regulate the rate of nitrification, e.g. supply of $\mathrm{NH}_{4}{ }^{+}$or $\mathrm{O}_{2}$ conditions, may also be important. A close coupling of these 2 processes has been found in many marine systems (Seitzinger 1988, Kemp et al. 1990, Devol 1991, Yoon \& Benner 1992, Devol \& Christensen 1993, Lohse et al. 1996). Since nitrification is an oxic process and denitrification mainly anoxic or suboxic, the most efficient coupling of nitrification and denitrification can be assumed to occur under moderate $\mathrm{O}_{2}$ concentrations where the 2 processes can be situated close to each other. At the eastern end of the Gulf of 
Finland at $\operatorname{Stn} \mathrm{F} 41$, the $\mathrm{O}_{2}$ concentrations were probably too high for efficient coupling. This is also supported by the very low rate of $D_{w}$ indicating that denitrification may have been restricted to deeper sediment layers (Fig. 6d; cf. Christensen et al. 1990).

The very low $\mathrm{O}_{2}$ concentrations 14.5 to $31 \mu \mathrm{M} 1 \mathrm{~m}$ above the bottom) at the deep Stns LL17 and LL23 in the northern Baltic Proper obviously limited nitrification and therefore denitrification. The lower percentage of $D_{n}$ compared to the other stations (Fig. 6e) further supports this. In addition, $\mathrm{HS}^{-}$has been found to inhibit denitrification (Sørensen et al. 1987) and nitrification (e.g. Joye \& Hollibaugh 1995). Although $\mathrm{HS}^{-}$ was not found in our samples $1 \mathrm{~m}$ above the bottom (data not shown), the sediment may well have contained it.

The effect of benthic fauna in the activation of denitrification has 2 routes. Directly, $D_{w}$ is activated by the pumping of $\mathrm{NO}_{3}{ }^{-}$from the overlying water into the burrows in the sediment. Indirectly, nitrification is high in the burrow walls (e.g. Kristensen 1988), which therefore activates $D_{\mathrm{n}}$. Other factors significant in the correlation analysis for $D_{w}$ and $D_{n}$, i.e. $\mathrm{NO}_{3}{ }^{-}$concentration, salinity, temperature and $\mathrm{O}_{2}$ concentration, all correlated significantly with each other. They reflect the presence of old, deep water from below the halocline with higher salinity and nutrient concentration, and lower $\mathrm{O}_{2}$ concentration. The presense of old, deep water was found to activate $D_{\mathrm{w}}$ but suppress $D_{\mathrm{n}}$. The non-periodical inflows of water to the Baltic Sea from the North Sea fill the basins in the Baltic Proper with highly saline water containing high temperature and $\mathrm{O}_{2}$ concentration (Matthäus \& Lass 1995). During stagnation the salinity, temperature and $\mathrm{O}_{2}$ concentration of this deep water decrease until the old water is replaced by the next inflow. The old water mass then continues its way towards the Gulf of Finland along the bottom. If long stagnation periods occur, the basins become filled with $\mathrm{H}_{2} \mathrm{~S}$ and no denitrification can therefore be expected to happen since $\mathrm{NO}_{3}{ }^{-}$cannot be produced by nitrification.

The denitrification rate was highest in late summer and early autumn. It has been found in many studies that denitrification was high in spring after the spring phytoplankton bloom with possibly another peak in the autumn (Jørgensen \& Sørensen 1988, Jørgensen 1989, Kemp et al. 1990, Jensen et al. 1996). However, Smith et al. (1985) and Yoon \& Benner (1992) found highest denitrification in late summer It must be noted that all these studies were made in relatively shallow areas where sedimentation of algae may have a more direct effect on the benthic processes. At Stns GF2 and JML (depths 84 and $80 \mathrm{~m}$, respectively), other factors are probably of greater importance since the algal material is largely decomposed when reaching the sediment (cf. Wassmann 1990). However, the reason for the seasonal rhythm remained unclear.

The peak of denitrification observed in January 1996 at Stn JML is surprising since the input of settling material is scarce at the end of the year. As there was only 1 measurement carried out during winter, it must be viewed with caution. However, Devol et al. (1997) have likewise found that the denitrification rate in the western Arctic shelf sediment did not differ between August-September and March although the sediment in March had not received fresh autochthonous settling material for months due to ice cover.

\section{Importance of denitrification in $\mathbf{N}$ cycling}

In estuaries, an average of 20 to $50 \%$ of external $\mathrm{N}$ input has been found to be released by denitrification (Smith et al. 1985, Jørgensen \& Sørensen 1988, Seitzinger 1988, Yoon \& Benner 1992, Christensen et al. 1996, Stockenberg \& Johnstone 1997). Calculated as an average for the area of the Gulf of Finland, the denitrification rate obtained in the present study is $45 \mathrm{kt} \mathrm{N} \mathrm{yr}^{-1}$. The loading of $\mathrm{N}$ to the Gulf of Finland via rivers and by direct discharges from coastal municipalities and industries was estimated to be $140 \mathrm{kt}$ in 1990 , and the annual total (wet + dry) atmospheric deposition ca $13 \mathrm{kt}$ in the late 1980s (HELCOM 1996), together giving a yearly $\mathrm{N}$ input of ca $153 \mathrm{kt}$. This gives release of ca $30 \%$ of the external $\mathrm{N}$ input by denitrification. However, this is only an estimate since denitrification was calculated from results obtained only from the open area of the Gulf of Finland. Nevertheless, the calculation probably gives a fairly correct estimate since the area of the open waters is by far larger than the area of the shallow and littoral waters. In addition, the area of the erosion bottoms where no or very little denitrification can be assumed to occur may be compensated for by the relatively more intense denitrification in the littoral areas. The value obtained is in good accordance with the 23 and $31 \%$ obtained for the Bothnian Bay and the Bothnian Sea, respectively, by Stockenberg \& Johnstone (1997).

The release of $\mathrm{N}_{2} \mathrm{O}$ during denitrification may also remove $\mathrm{N}$ from the ecosystem. However, the formation of $\mathrm{N}_{2} \mathrm{O}$ during denitrification has been found to be minor $(0$ to $10 \%)$ in marine systems (Smith \& DeLaune 1983, Seitzinger 1988, Capone 1991); $\mathrm{N}_{2} \mathrm{O}$ may even be consumed during denitrification (Capone 1991). $\mathrm{N}_{2} \mathrm{O}$, although advantageous for the $\mathrm{N}$ removal from eutrophicated marine systems together with $N_{2}$, is harmful as a greenhouse gas (Dickenson \& Cicerone 1986) and a participant in the destruction of stratospheric ozone (Cicerone 1987). 
Although release of $\mathrm{N}$ by denitrification was quite efficient in the Gulf of Finiand, it cannot be counted on that denitrification will compensate for increased $N$ loading. Seitzinger \& Nixon (1985) have found that under experimental nutrient addition, although denitrification rate increased, the amount of $\mathrm{N}$ removed was a constant or progressively smaller fraction of the $\mathrm{N}$ input. In an extreme situation, observed in the Chesapeake Bay (Kemp et al. 1990), denitrification could be totally eliminated during midsummer since anoxic conditions led to the elimination of nitrification and subsequent coupled denitrification. This leads to a vicious circle where eutrophication catalyzes itself through repression of denitrification. In the Baltic Sea, this possibility is further enabled since the non-periodical inflows of highly saline water cause anoxic periods which can be prolonged and extended by eutrophication.

Acknowledgements. We are indebted to Riikka Oja, Susanna Hietanen and the crew of the research vessels for help in the field and laboratory. We thank Ann-Britt Andersin, Hannu Haahti, Susanna Hietanen, Leena Karjala and Jaana Räty from the Finnish Institute of Marine Research for providing us background information and Kalervo Mäkelä for ideas. This study was part of the BASYS project funded by the EU through the MAST programme (contract MAS3-CT96-0058),

\section{LITERATURE CITED}

Alasaarela E, Tolonen E, Eloranta V (1986) Nutrients regulating algal growth in the Bothnian Bay. Ophelia Suppl 4: 323-328

Brettar I, Rheinheimer G (1991) Denitrification in the Central Baltic: evidence for $\mathrm{H}_{2} \mathrm{~S}$-oxidation as motor of denitrification at the oxic-anoxic interface. Mar Ecol Prog Ser 77: $157-169$

Brettar I, Rheinheimer G (1992) Influence of carbon availability on denitrification in the central Baltic Sea. Limnol Oceanogr 37:1146-1163

Capone DG (1991) Aspects of the marine nitrogen cycle with relevance to the dynamics of nitrous and nitric oxide. In: Rogers JE, Whitman WB (eds) Microbial production and consumption of greenhouse gases: methane, nitrogen oxides, and halomethanes. American Society for Microbiology, Washington, DC, p 255-275

Christensen JP, Townsend DW, Montoya JP (1996) Water column nutrients and sedimentary denitrification in the Gulf of Maine. Cont Shelf Res 16:489-515

Christensen PB, Nielsen LP, Sørensen J, Revsbech NP (1990) Denitrification in nitrate-rich streams: diurnal and seasonal variation related to benthic oxygen metabolism. Limnol Oceanogr 35:640-651

Cicerone RJ (1987) Changes in stratospheric ozone. Science $237: 35-42$

Devol AH (1991) Direct measurement of nitrogen gas fluxes from continental shelf sediments. Nature 349:319-321

Devol AH, Christensen JP (1993) Benthic fluxes and nitrogen cycling in sediments of the continental margin of the eastern North Pacific. J Mar Res 51:345-372

Devol AH, Codispoti LA, Christensen JP (1997) Summer and winter denitrification rates in western Arctic shelf sedi- ments. Cont Shelf Res 17:1029-1050

Dickenson RE, Cicerone RJ (1986) Future global warming from atmospheric trace gases. Nature 319:109-115

Granéli E, Wallström K, Larsson U, Granéli W, Elmgren R (1990) Nutrient limitation of primary production in the Baltic Sea area. Ambio 19:142-151

Grasshoff K (1983) Methods of seawater analysis, 2nd edn. Verlag Chemie, Weinheim

HELCOM (1996) Third periodic assessment of the state of the marine environment of the Baltic Sea, 1989-1993; background document. Balt Sea Environ Proc No. 64 B

Henriksen K, Kemp WM (1988) Nitrification in estuarine and coastal marine sediments. In: Blackburn TH, Sarensen J (eds) Nitrogen cycling in coastal marine environments. John Wiley \& Sons Ltd, Chichester, p 207-249

Jensen KM, Jensen MH, Kristensen E (1996) Nitrification and denitrification in Wadden Sea sediments (Königshafen, Island of Sylt, Germany) as measured by nitrogen isotope pairing and isotope dilution. Aquat Microb Ecol 11. $181-191$

Jorgensen KS (1989) Annual pattern of denitrification and nitrate ammonification in estuarine sediment. Appl Environ Microbiol 55:1841-1847

Jørgensen KS, Sørensen J (1988) Two annual maxima of nitrate reduction and denitrification in estuarine sediment (Norsminde Fjord, Denmark). Mar Ecol Prog Ser 48: $147-154$

Joye SB, Hollibaugh JT (1995) Influence of sulfide inhibition of nitrification on nitrogen regeneration in sediments. Science 270:623-625

Kankaanpää $H$, Vallius $H$, Sandman O, Niemistö L (1997) Determination of recent sedimentation in the Gulf of Finland using ${ }^{137} \mathrm{Cs}$. Oceanol Acta 20:823-836

Kemp WM, Sampou P, Caffrey J, Mayer M, Henriksen K, Boynton WR (1990) Ammonium recycling versus denitrification in Chesapeake Bay sediments. Limnol Oceanogr 35:1545-1563

Kester DR (1975) Dissolved gases other than $\mathrm{CO}_{2}$. In: Riley JP, Skirrow G (eds) Chemical oceanography, Vol 1, 2nd edn. Academic Press, London, p 497-556

Kivi K, Kaitala S, Kuosa H, Kuparinen J, Leskinen E, Lignell R, Marcussen B, Tamminen T (1993) Nutrient limitation and grazing control of Baltic plankton community during annual succession. Limnol Oceanogr 38:893-905

Koike I, Sørensen J (1988) Nitrate reduction and denitrification in marine sediments. In: Blackburn TH, Sørensen $J$ (eds) Nitrogen cycling in coastal marine environments. John Wiley \& Sons Ltd, Chichester, p 251-273

Koop K, Boynton WR, Wulff F, Carman R (1990) Sedimentwater oxygen and nutrient exchanges along a depth gradient in the Baltic Sea. Mar Ecol Prog Ser 63:65-77

Kristensen E (1988) Benthic fauna and biogeochemical processes in marine sediments: microbial activities and fluxes. In: Blackburn TH, Sørensen J (eds) Nitrogen cycling in coastal marine environments. John Wiley \& Sons Ltd, Chichester, p 275-299

Laine AO, Sandler H, Andersin AB, Stigzelius J (1997) Longterm changes of macrozoobenthos in the Eastern Gotland Basin and the Gulf of Finland (Baltic Sea) in relation to the hydrographical regime. J Sea Res 38:135-159

Lohse L, Kloosterhuis HT, van Raaphorst W, Helder W (1996) Denitrification rate as measured by the isotope pairing method and by the acetylene inhibition technique in continental shelf sediments of the North Sea. Mar Ecol Prog Ser 132:169-179

Matthäus W, Lass HU (1995) The recent salt inflow into the Baltic Sea. J Phys Oceanogr 25:280-286 
Middelburg JJ, Soetaert K, Herman PMJ (1996) Evalution of the nitrogen isotope-pairing method for measuring benthic denitrification: a simulation analysis. Limnol Oceanogr 41:1839-1844

Nielsen LP (1992) Denitrification in sediment determined from nitrogen isotope pairing. FEMS Microb Ecol 86: $357-362$

Nielsen LP, Risgaard-Petersen N, Rysgaard S, Blackburn TH (1996) Reply to the note by Middelburg et al. Limnol Oceanogr 41:1845-1846

Nowicki BL, Requintina E, Van Keuren D. Kelly JR (1997) Nitrogen losses through sediment denitrification in Boston Harbor and Massachusetts Bay. Estuaries 20:626-639

Ogilvie B, Nedwell DB, Harrison RM, Robinson A, Sage A (1997) High nitrate, muddy estuaries as nitrogen sinks: the nitrogen budget of the River Colne estuary (United Kingdom). Mar Ecol Prog Ser 150:217-228

Pelegrí SP, Nielsen LP, Blackburn TH (1994) Denitrification in estuarine sediment stimulated by the irrigation activity of the amphipod Corophium volutator. Mar Ecol Prog Ser 105:285-290

Perttilä M, Niemıstö L, Mäkelä K (1995) Distribution, development and total amounts of nutrients in the Gulf of Finland. Estuar Coast Shelf Sci 41:345-360

Rahm L, Conley D, Sandén P, Wulff F, Stålnacke P (1996) Time series analysis of nutrient inputs to the Baltic Sea and changing DSi:DIN ratios. Mar Ecol Prog Ser 130: $221-228$

Rinne I (1988) Typenpoiston tarpeellisuus Helsingin ja Espoon kaupunkien jätevesistä. (Need for nitrogen removal from Helsinki and Espoo wastewaters). In: Pesonen L (ed) Helsingin ja Espoon edustan merialueiden velvoitetarkkailu vuosina 1970-1986. Tutkimustoimiston. tiedonantoja 1.7:215-256

Risgaard-Petersen N, Rysgaard S, Nielsen LP, Revsbech NP (1994) Durnal variation of denitrification and nitrification in sediments colonized by benthic microphytes. Limnol Oceanogr 39:573-579

Rönner U (1985) Nitrogen transformations in the Baltic Proper denitrification counteracts eutrophication. Ambio $14: 134-138$

Rönner U, Sörensson F (1985) Denitrification rates in the lowoxygen waters of the stratified Baltic Proper. Appl Environ Microbiol 50:801-806

Rysgaard S, Risgaard-Petersen N, Nielsen LP, Revsbech NP (1993) Nitrification and denitrification in lake and estuarine sediments measured by the ${ }^{15} \mathrm{~N}$ dilution technique and isotope pairing. Appl Environ Microbiol 59:2093-2098

Seitzinger SP (1988) Denitrification in freshwater and coastal marine ecosystems: ecological and geochemical significance. Limnol Oceanogr 33:707-724

Editorial responsibility: Otto Kinne (Editor), Oldendorf/Luhe, Germany
Seitzinger SP, Giblin AE (1996) Estimating denitrification in North Allantic continental shelf sediments. Biogeochemistry 35:235-260

Seitzinger SP, Nielsen LP, Caffrey J, Christensen PB (1993) Denitrification measurements in aquatic sediments: a comparison of three methods. Biogeochemistry 23: $147-167$

Seitzinger SP, Nixon SW (1985) Eutrophication and the rate of denitrification and $\mathrm{N}_{2} \mathrm{O}$ production in coastal marine sediments. Limnol Oceanogr 30:1332-1339

Seppänen $H$ (1992) Typenpoiston tarpeellisuudesta. (On the necessity of reducing $\mathrm{N}$ in waste water.) Vesitalous 33(1): $6-11$

Shaffer G, Rönner U (1984) Denitrification in the Baltic Proper deep water. Deep-Sea Res 31:197-220

Smith CJ, DeLaune RD (1983) Nitrogen loss from freshwater and saline estuarine sediments. I Environ Qual 12: $514-518$

Smith CJ, DeLaune RD, Patrick WH Jr (1985) Fate of riverine nitrate entering an estuary: I. Denitrification and nitrogen burial. Estuaries 8:15-21

Sorensen J, Rasmussen LK, Koike I (1987) Micromolar sulfide concentrations alleviate acutylene blockage of nitrous oxide reduction by denitrifying Pseudomonas fluorescens. Can J Microbiol 33:1001-1005

Stockenberg A, Johnstone RW (1997) Benthic denitrification in the Gulf of Bothnia. Estuar Coast Shelf Sci 45:835-843

Tamminen T (1992a) Itämeren typpikysymys-ympäristölogiikan musta aukko? (Nitrogen in the Baltic Sea: the black hole of environmental logic.) Vesitalous 33(2):11-16

Tamminen $T$ (1992b) Typenpoiston tarpeettomuudesta: typensidonta, myrkkylevät ja denitrifikaatio Suomenlahden vesiensuojelukeskustelussa. (On the unnecessity of reducing $\mathrm{N}$ in waste water: nitrogen fixation, toxic algae and denitrification in the Gulf of Finland water protection debate.) Vesitalous 33(2):18-23

Trimmer M, Nedwell DB, Sivyer DB, Malcolm SJ (1998) Nitrogen fluxes through the lower estuary of the river Great Ouse, England: the role of bottom sediments. Mar Ecol Prog Ser 163:109-124

Wassmann P (1990) Relationship between primary and export production in the boreal coastal zone of the North Atlantic. Limnol Oceanogr 35:464-471

Winterhalter B (1972) On the geology of the Bothnuan Sea, an epeiric sea that has undergone Pleistocene glaciation. Geol Surv Fin Bull 258:1-66

Wulff F, Stigebrandt A, Rahm L (1990) Nutrient dynamics of the Baltic Sea. Ambio 19:126-133

Yoon WB, Benner R (1992) Denitrification and oxygen consumption in sediments of two south Texas estuaries. Mar Ecol Prog Ser 90:157-167

Submitted: February 25, 1998; Accepted: July 31, 1998 Proofs recelved from author(s): September 30, 1998 